\title{
ЕФЕКТИВНІСТЬ АГРАРНОГО ВИРОБНИЦТВА В ПОЛТАВСЬКІЙ ОБЛАСТІ ТА НАПРЯМИ УДОСКОНАЛЕННЯ МЕХАНІЗМІВ РЕГУЛЮВАННЯ ЙОГО РОЗВИТКУ
}

\section{Рецензент - кандидат економічних наук, професор В. І. Аранчій}

\begin{tabular}{|} 
Проведено аналіз рівня, динаміки та ефективності \\
аграрного виробництва в Полтавській області. \\
Розроблено організаційно-економічний механізм \\
підтримки розвитку аграрного підприємництва на \\
регіональному рівні, який повинен бути елементом \\
національної програми розвитку аграрного секто- \\
ра Украӥни. Запропоновано застосувати процесний \\
та програмно-цільовий підхід для формування ме- \\
ханізму державної підтримки розвитку аграрного \\
підприємництва на регіональному рівні як ичілісної \\
системи.
\end{tabular}

Ключові слова: аграрне виробництво, ефективність, регулювання, розвиток, підтримка, організаційно-економічний механізм.

Постановка проблеми. Агропромисловий комплекс Полтавської області в радянський період мав у своєму розпорядженні могутній потенціал, який за використовуванням прогресивних технологій, рівнем собівартості продукції, рентабельністю виробництва, урожайністю основних сільськогосподарських культур та продуктивністю тварин, інтенсивністю виробничої діяльності знаходився на рівні передових світових стандартів.

Перехідна економіка України визначила негативні аспекти формування агропромислового комплексу регіону: штучний відрив фінансової системи від сільськогосподарського виробництва, недосконала кредитна та податкова політика, низька платоспроможність сільськогосподарських товаровиробників, висока кредиторська заборгованість, обмежений обсяг обігових коштів. Фінансова криза останніх років призвела власне до зупинення інвестиційних процесів в аграрній сфері, руйнування матеріально-технічного потенціалу сільського господарства, припинення оновлення машино-технологічного парку, погіршення забезпечення сільськогосподарського виробництва механізаторськими та інженернотехнічними кадрами.

Однією з головних умов відновлення виробничого потенціалу та забезпечення економічного зростання аграрного виробництва, досягнення сталого розвитку аграрних підприємств і сільських територій $є$ створення системи механізмів їх економічного регулювання як на регіональному, так і на загальнодержавному рівнях.

Аналіз основних досліджень і публікацій, у яких започатковано розв'язання проблеми. Проблеми розвитку, підвищення ефективності та економічного регулювання аграрного виробництва розкриті в працях таких відомих вчених, як В. Андрійчука [1], В. Амбросова [2], М. Дем'яненка [3], П. Макаренка [4], М. Маліка [5], П. Саблука [6], О. Шпикуляка [8], В. Юрчишина [9] та інших.

Проте в літературних джерелах недостатньо висвітленими залишаються питання ринкової трансформації централізовано-планових форм i методів управління, а також комплексного дослідження проблеми економічного регулювання аграрного виробництва 3 урахуванням зміни внутрішніх i зовнішніх чинників та концептуального забезпечення цього процесу після завершення трансформаційного періоду відновлення агроресурсного потенціалу економіки країни. Наукові дослідження 3 цієї тематики спрямовуються переважно на вирішення окремих актуальних питань, розглядаються під галузевокорпоративним кутом зору, а в рекомендаціях щодо їх удосконалення не простежується системного підходу.

Метою роботи $\epsilon$ аналіз сучасного рівня та ефективності аграрного виробництва в Полтавській області й вивчення необхідності та можливостей його економічного регулювання в сучасних умовах.

Результати дослідження. Сфера аграрного виробництва характеризується певними чинниками впливу на діяльність аграрних підприємств. Основними з них є попит на сільськогосподарську продукцію та сировину на внутрішньому i зовнішніх ринках, механізм ціноутворення, наявність або відсутність державної підтримки товаровиробників, ступінь концентрації виробництва та ii спеціалізація, рівень розвитку інфра- 
структури аграрного ринку тощо. Проблема організації ефективного виробництва сільськогосподарської продукції в Україні полягає у тому, що за часів адміністративного управління економікою завдання створити ринкове середовище 3 притаманними йому законами вартості, рівноваги попиту і пропозиції та конкуренції просто не ставилося. На сучасному етапі відчуваються проблеми щодо ефективного формування й використання ресурсів у процесі виробництва продукції. Так, основні засоби аграрних підприємств Полтавської області мають високий ступінь зносу, більшість суб'єктів господарювання не мають змоги забезпечити оновлення технікотехнологічної бази виробництва через фінансово-кредитні механізми, подорожчання посівних i пально-мастильних матеріалів призводить до зростання собівартості виробництва й реалізації сільськогосподарської продукції при невідповідності державним закупівельним цінам. Система управління аграрним сектором Полтавської області потребує удосконалення та реорганізації організаційної структури, а персонал - постійного підвищення кваліфікації. Фінансові активи суб'єктів господарювання аграрної сфери регіону носять обмежений характер через відсутність власних оборотних коштів та неможливість до- ступу до кредитних ресурсів.

У 2010 році загальне виробництво продукції сільського господарства у Полтавській області порівняно з 2006 роком збільшилося на 2,6\% (табл. 1), у тому числі в сільськогосподарських підприємствах - на 14,8 \%, у той час, як у господарствах населення знизилося на 8,3\%. Проте, порівняно 3 попереднім роком, виробництво валової продукції сільського господарства значно зменшилось, передусім у сільськогосподарських підприємствах (за винятком виробництва продукції тваринництва). Тобто, незважаючи на ріст аграрного виробництва протягом 2006-2009 pр., який був зумовлений переважно збільшенням виробництва в аграрних підприємствах, у 2010 році обсяги виробництва сільськогосподарської продукції зменшилися, що відбулося внаслідок зменшення виробництва в тих же аграрних підприємствах.

Виробництво продукції рослинництва у 2010 р., порівняно з 2006 р. зросло на 7,5\%, у тому числі у сільськогосподарських підприємствах - на 13,7 \%, у господарствах населення - на 1,3\%. У розрізі окремих видів продукції найвідчутніше зросло виробництво плодів, зернових і технічних культур.

\section{1. Рівень та динаміка виробництва валової продукції сільського господарства у Полтавській області в порівняльних цінах 2005 р., млн грн}

\begin{tabular}{|c|c|c|c|c|c|c|}
\hline \multirow{2}{*}{ Показник } & \multicolumn{5}{|c|}{ Роки } & \multirow{2}{*}{$\begin{array}{l}\text { 2010. у \% } \\
\text { до } 2006 \text { p. }\end{array}$} \\
\hline & 2006 & 2007 & 2008 & 2009 & 2010 & \\
\hline \multicolumn{7}{|c|}{ Усі категорії господарств } \\
\hline $\begin{array}{c}\text { Продукція сільського господарства, } \\
\text { усього }\end{array}$ & 4964,4 & 5069,4 & 5729,8 & 5700,2 & 5095,4 & 102,6 \\
\hline Продукція рослинництва & 3300,6 & 3497,7 & 4309,3 & 4143,5 & 3548,7 & 107,5 \\
\hline Продукція тваринництва & 1663,8 & 1571,7 & 1420,5 & 1556,7 & 1546,7 & 93,0 \\
\hline \multicolumn{7}{|c|}{ Сільськогосподарські підприємства } \\
\hline $\begin{array}{c}\text { Продукція сільського господарства, } \\
\text { усього }\end{array}$ & 2355,6 & 2572,5 & 3275,3 & 3094,1 & 2703,1 & 114,8 \\
\hline Продукція рослинництва & 1657,6 & 1871,6 & 2557,6 & 2301,9 & 1883,9 & 113,7 \\
\hline Продукція тваринництва & 698,0 & 700,9 & 717,7 & 792,2 & 819,2 & 117,4 \\
\hline \multicolumn{7}{|c|}{ Господарства населення } \\
\hline $\begin{array}{c}\text { Продукція сільського господарства, } \\
\text { усього }\end{array}$ & 2608,8 & 2496,9 & 2454,5 & 2606,1 & 2392,3 & 91,7 \\
\hline Продукція рослинництва & 1643,0 & 1626,1 & 1751,7 & 1841,6 & 1664,8 & 101,3 \\
\hline Продукція тваринництва & 965,8 & 870,8 & 702,8 & 764,5 & 727,5 & 75,3 \\
\hline \multicolumn{7}{|c|}{ Вироблено продукиії (усі категорії господарств) } \\
\hline На одну особу, грн & 3207,6 & 3307,5 & 3774,2 & 3786,3 & 3411,3 & 106,4 \\
\hline $\begin{array}{c}\text { На } 100 \text { га сільськогосподарських } \\
\text { угідь, тис. грн }\end{array}$ & 260,4 & 266,4 & 296,1 & 295,8 & 264,9 & 101,7 \\
\hline
\end{tabular}

Джерело: розраховано автором на основі [7] 
EKOHOMIKA

2. Ефективність сільськогосподарського виробництва в аграрних підприсмствах Полтавської області

\begin{tabular}{|c|c|c|c|c|c|c|}
\hline Показник & \multicolumn{5}{|c|}{ Роки } & \multicolumn{2}{c|}{2010 р. до } \\
\cline { 2 - 6 } & 2006 & 2007 & 2008 & 2009 & 2010 & 2006 р. (+;-) \\
\cline { 1 - 6 } $\begin{array}{c}\text { Прибуток, збиток (-) від реалізації } \\
\text { сільськогосподарської продукції, } \\
\text { млн грн }\end{array}$ & $-6,1$ & 514,1 & 335,8 & 533,4 & 1062,2 & 1068,3 \\
\hline Продукція рослинництва & 68,3 & 541,6 & 375,4 & 490,4 & 987,7 & 919,4 \\
\hline Продукція тваринництва & $-74,4$ & $-27,5$ & $-39,6$ & 43,0 & 74,5 & 148,9 \\
\hline $\begin{array}{c}\text { Рівень рентабельності виробництва } \\
\text { сільськогосподарської продукції, \% }\end{array}$ & $-0,4$ & 28,7 & 11,3 & 15,5 & 21,7 & 22,1 \\
\hline Продукція рослинництва & 7,0 & 46,9 & 17,9 & 19,4 & 28,0 & 21,0 \\
\hline Продукція тваринництва & $-14,5$ & $-4,3$ & $-4,6$ & 4,7 & 5,4 & 19,9 \\
\hline
\end{tabular}

Джерело: розраховано автором на основі [7]

Аналіз ефективності господарської діяльності сільськогосподарських підприємств за 2010 рік свідчить (табл. 2), що їх фінансово-економічний стан поліпшився. В цілому сільськогосподарські підприємства одержали прибутку в сумі 1062,2 млн грн (за 2009 рік - 533,4 млн грн), в той час як у 2006 році спостерігався збиток. У 2009-2010 рр. прибутковим було виробництво як продукції рослинництва, так і тваринництва.

Ефективність ринкової системи господарювання в аграрній сфері залежить від активної регулюючої функції держави та продукування нею економічних умов для розвитку виробництва в підприємницьких структурах. 3 огляду на це, ефективність функціонування агроекономічної системи залежить від раціонального вирішення питань розвитку аграрної економіки на мікрорівні.

Розробку та реалізацію державної політики розвитку аграрного виробництва забезпечують органи державної виконавчої влади відповідно до своєї компетенції й повноважень у взаємодії 3 підприємницькими структурами, об'єднаннями підприємців, громадськими організаціями та спілками, фінансово-кредитними установами. Слід підкреслити, що в ефективному розвитку аграрного виробництва насамперед зацікавлений регіон. По-перше, значна частка цього сектора економіки орієнтована на регіональний ринок. По-друге, збільшення кількості та ефективності діяльності суб'єктів аграрного підприємництва сприятиме створенню нових робочих місць, тим самим полегшуючи проблему безробіття в сільській місцевості. По-третє, пропорційно росту кількості підприємств та їх ефективності, зі збільшенням обсягів виробництва зростають податкові надходження до місцевих бюджетів. Регіональна політика управління розвитком аграрного бізнесу виходить із того, що основні функції управління переносяться на регіональний та місцевий рівні.

Державна підтримка розвитку аграрного підприємництва на регіональному рівні є науковим інструментом довготермінового прогнозування, індикативного планування, засобом вирішення регіональних, державних та міжрайонних проблем. При цьому головний управлінський акцент повинен бути спрямований на розвиток інфраструктури, системи управління сільськогосподарським виробництвом, місцевою переробною промисловістю, сферою послуг, а також ефективним використанням місцевих ресурсів.

Виходячи з визначеної сукупності мети, функцій, методів, форм управління, нами запропонований організаційно-економічний механізм підтримки розвитку аграрного підприємництва на регіональному рівні. Організаційно-економічний механізм підтримки розвитку аграрного підприємництва повинен бути елементом національної програми розвитку аграрного сектора України й охоплювати принципи, функції, методи управління, форми та інструменти підтримки аграрного підприємництва; суб'єкт управління, аналіз розвитку аграрного виробництва та зовнішнього середовища його функціонування, об'єкт управління (див. рис.).

Для формування механізму державної підтримки розвитку аграрного підприємництва на регіональному рівні як цілісної системи пропонуємо застосувати процесний та програмно-цільовий підхід. Суть процесного підходу полягає в тому, що державна підтримки розглядається як серія взаємопов'язаних управлінських функцій. Суть програмно-цільового підходу полягає в розробці політики реалізації стратегічних напрямів та найактуальніших програм вирішення соціальноекономічних проблем регіону й передбачає 


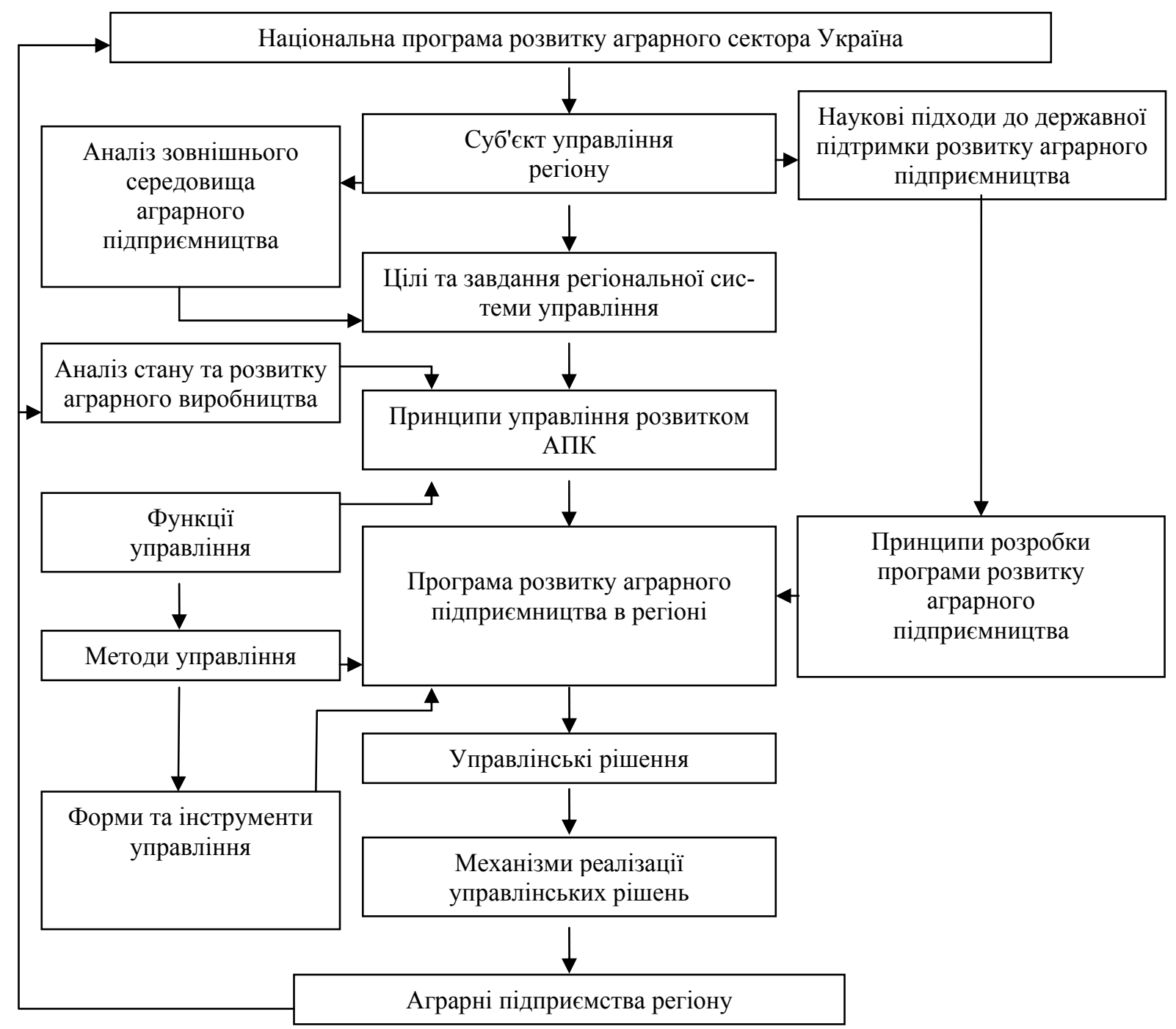

\section{Рис. Організаційно-економічний механізм підтримки розвитку аграрного підприємництва на регіональному рівні}

визначення комплексу взаємопов'язаних організаційно-правових і фінансово-економічних заходів, спрямованих на їх виконання.

Процес державної підтримки розвитку аграрного підприємництва включає наступні етапи: аналіз стану та розвитку аграрного виробництва регіону; розробку регіональної програми розвитку аграрного підприємництва; прийняття управлінських рішень; контроль за виконанням цих рішень.

Важливою складовою організаційно-економічного механізму державної підтримки розвитку аграрного підприємництва $є$ принципи, які слід розглядати у двох площинах: принципи регіональної системи управління аграрним підприємництвом і принципи розробки програми розвитку аграрного підприємництва.

Методологічну основу побудови організаційно-економічного механізму державної підтримки розвитку аграрного підприємництва становлять загальні теоретичні принципи, на базі яких повинна розроблятися остання: відповідність характеру та рівню розвитку аграрного підприємництва в регіоні; відповідність цілям розвитку керованої економічної системи; інтегрованість різних економічних інтересів усіх учасників господарського процесу в аграрному секторі; забезпеченість мотивації всіх учасників цього процесу.

\section{Висновки:}

1. Проведене дослідження сучасного стану сільськогосподарського виробництва в Полтавської області свідчить про зміни обсягів діяльності суб'єктів господарювання аграрної сфери, що зумовлено ринковою кон'юнктурою. Економічні відносини в агропромисловому комплексі мають нестабільний характер взаємодії між суб'єктами виробництва та іншими контрагентами, включаючи державні органи різного рівня управління, 
що вимагає необхідності удосконалення механізму підтримки розвитку аграрних підприємств.

2. Розроблено організаційно-економічний механізм підтримки розвитку аграрного підприємництва на регіональному рівні, який повинен бути елементом національної програми розвитку аграрного сектора України й охоплювати принципи, функції, методи управління, форми та інструменти підтримки аграрного підприємництва, суб'єкт управління, аналіз розвитку аграрного

\section{БІБЛІОГРАФІЯ}

1. Андрійчук В. Г. Сучасна аграрна політика: проблемні аспекти / В. Г. Андрійчук, М.В. Зубець, В. В. Юрчишин. - К. : Аграрна наука, 2005. $-140 \mathrm{c}$.

2. Амбросов В. Я. Наукові положення удосконалення економічного і господарського механізмів розвитку сільського господарства / В. Я. Амбросов, Т. Г. Маренич // Економіка АПК. - 2005. № 10. - С. 14-19.

3. Дем'яненко М. Я. Проблемні питання державної політики фінансової підтримки сільського господарства / М. Я. Дем'яненко // Економіка АПК. - 2011. - № 7. - С. 67-75.

4. Макаренко П. М. Моделі аграрної економіки / П. М. Макаренко. - К. : ННЦ IAЕ, 2005. - 682 с. 5. Малік М. Й. Державне регулювання аграрного сектору економіки в дослідженнях вітчизняних виробництва i зовнішнього середовища його функціонування, об'єкт управління.

3. Політика підтримки аграрного підприємництва на регіональному рівні є більш ефективною через те, що регіональні структури влади краще володіють проблемами, 3 якими стикаються в процесі здійснення своєї діяльності аграрні підприємства, - вони мають можливість проводити всі заходи більш адресно, з урахуванням пріоритетних напрямів розвитку аграрного виробництва.

вчених / М. Й. Малік, Ю. О. Лупенко // Економіка АПК. - 2009. - № 10. - С. 153-158.

6. Саблук П. Т. Основні напрями удосконалення державної аграрної політики в Україні / П. Т. Саблук, Ю. Я. Лузан // Економіка АПК. 2011. - № 5. - С. 3-16.

7. Статистичний щорічник Полтавської області за 2010 рік. - Полтава : Головне управління статистики у Полтавській області. - 2011. -408 с.

8. Шпикуляк О. Г. Інституції у розвитку та регулюванні аграрного ринку : монографія / О.Г. Шпикуляк - К. : ННЦ IAE, 2010. - 74 с.

9. Юрчишин B. В. Науково-методологічні та організаційні основи розвитку системи управління аграрним сектором економіки / В. В. Юрчишин // Економіка АПК. - 2003. - № 1. - С. 17-25. 